\title{
An unusual oesophageal mass - a case of dissecting oesophageal haematoma
}

\author{
Fenella Marley, ${ }^{1}$ Hedvig Karteszi, ${ }^{2}$ Sally Norton, ${ }^{3}$ James Orr ${ }^{1}$
}

${ }^{1}$ Hepatology, Bristol Royal Infirmary, Bristol, UK ${ }^{2}$ Radiology, Bristol Royal Infirmary, Bristol, UK ${ }^{3}$ Hepatopancreatobiliary Surgery, Bristol Royal Infirmary, Bristol, UK

\section{Correspondence to} Dr Fenella Marley, fenella.marley@nhs.net

Accepted 7 February 2019

\section{DESCRIPTION}

A 59-year-old man presented to his general practitioner with dysphagia and was referred for an urgent outpatient upper GI endoscopy. He gave a history of symptoms suggestive of food bolus obstruction, which spontaneously resolved with vomiting 4 weeks ago. Following this he had odynophagia and chest pain and had a single episode of haematemesis 3 days prior to endoscopy. Past medical history included alcohol excess. He had a normal upper GI endoscopy 10 years ago. There was no history of weight loss and the patient was not anticoagulated.

Endoscopy showed a large, smooth submucosal lesion extending along the length of the oesophagus filling around half of the lumen. The mucosa appeared to have a linear split and was ulcerated and friable (figure 1) The lesion was non-pulsatile and there was no evidence of recent bleeding. Differential diagnoses for these endoscopic appearances include tumours (such as gastrointestinal stromal tumour [GIST] or leiomyoma), cystic lesions or aortic dissection.

A CT of thorax and abdomen was arranged. This confirmed the presence of an elongated lesion extending along the anterior oesophagus and protruding into the lumen of the oesophagus, measuring 3.5 transverse (TR) x 2.6 anteroposterior (AP) and extending over $28 \mathrm{~cm}$ in length. (figure 2) The lesion was predominantly hypodense with occasional hyper-attenuation. MRI imaging was not performed in this case, but would have been useful in further characterising the nature of the lesion.

A diagnosis of dissecting oesophageal haematoma was confirmed on endoscopic ultrasound (EUS). EUS (figure 3) showed a submucosal collection with no involvement of the extramural tissues of the posterior mediastinum. This appeared to be confined to the mucosal and submucosal layers and was felt to be

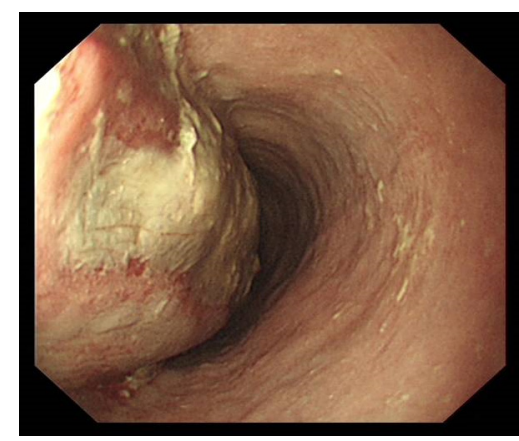

Figure 1 Oesophageal appearances at initial oesophagogastroduodenoscopy (OGD).

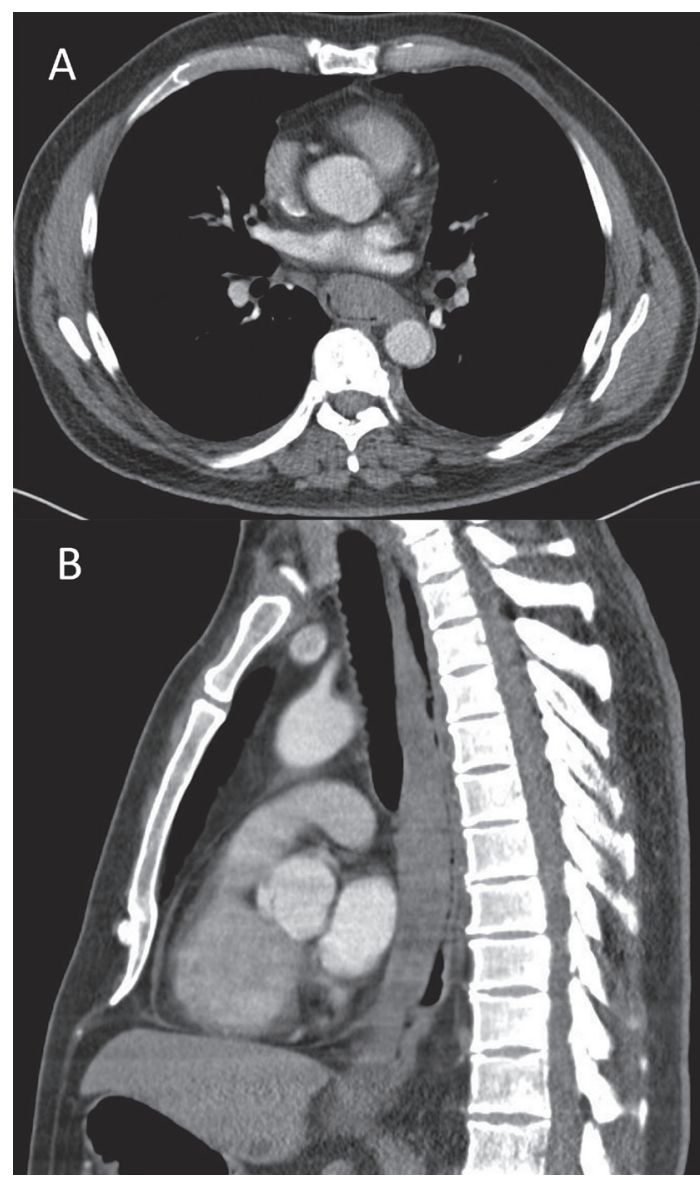

Figure 2 CT of thorax and abdomen on admission, showing intramural oesophageal collection visible on both transverse (A) and sagittal (B) sections.

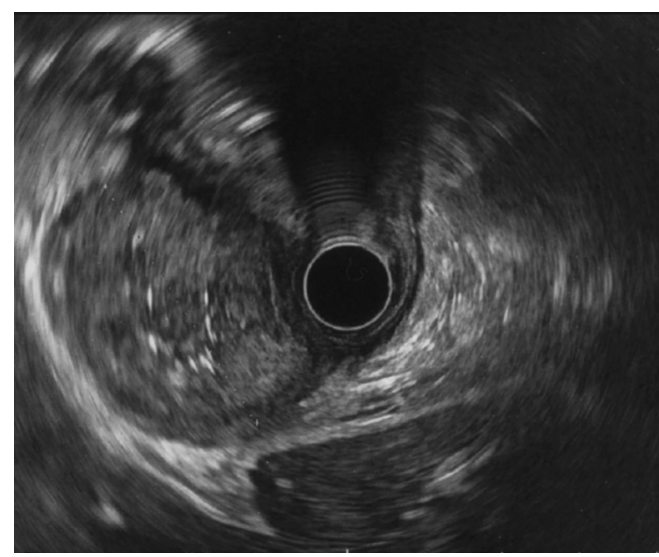

Figure 3 Oesophageal appearances at initial endoscopic ultrasound . 


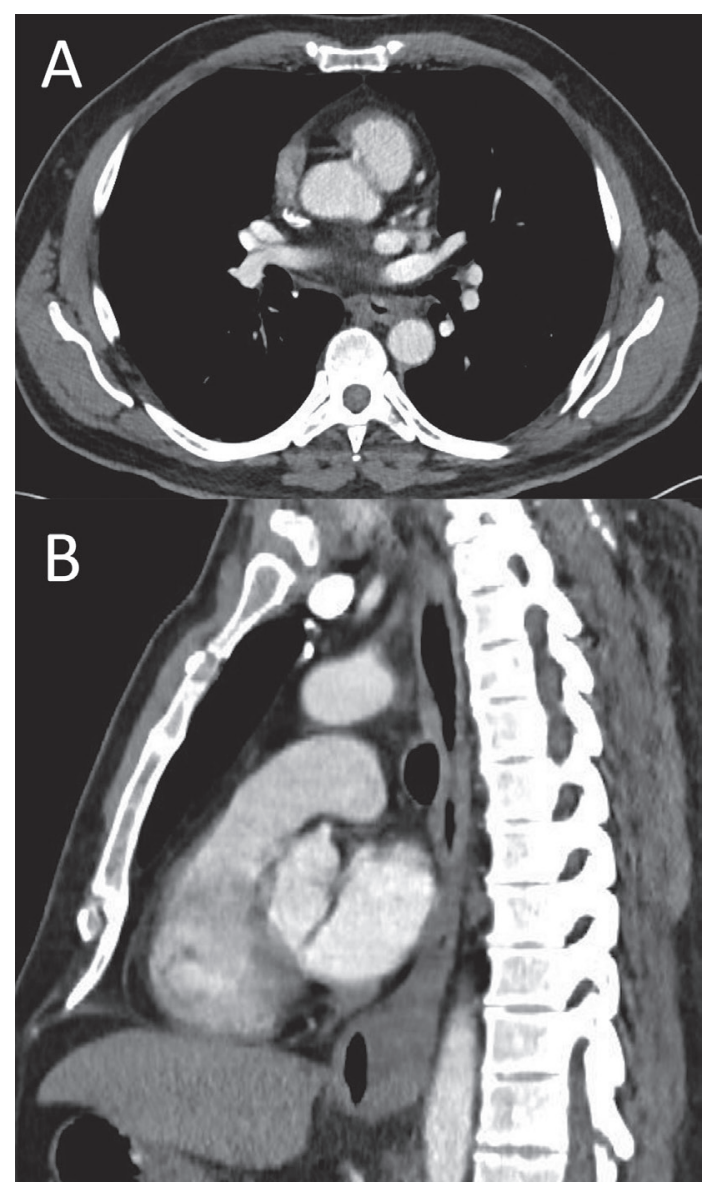

Figure 4 CT of thorax and abdomen 3 weeks after admission showing reduction in the size of the oesophageal intramural collection in both transverse (A) and sagittal (B) sections.

consistent with a diagnosis of a dissecting intramural haematoma secondary to a Mallory-Weiss tear, likely sustained during vomiting following an impacted food bolus.

Oesophageal haematomas have been reported with a range of aetiologies including uncontrolled hypertension ${ }^{1}$ and food bolus. ${ }^{2}$ It has been postulated that an oesophageal intramural haematoma may represent an intermediate stage between a Mallory-Weiss tear and Boerhaave's syndrome. ${ }^{3}$ Typically, presentation is with a triad of chest pain, haematemesis and dysphagia. Management is usually conservative with analgesia and correction of any coagulopathy. ${ }^{3}$

Our patient was initially admitted to a high-dependency area with frequent monitoring of observations and full blood count to ensure there was no evidence of ongoing bleeding. Supportive treatment with intravenous fluids and analgesia were given. Drug history was reviewed and there was no history of non-steroidal anti-inflammatory drugs, anticoagulants or antiplatelet prescription. Prophylaxis against venous thromboembolism was withheld. The patient was kept nil by mouth for 24 hours and was then given a soft diet for 24 hours before resuming normal diet. He was discharged after 4 days with oral analgesia and outpatient follow-up. CT of thorax and abdomen was repeated after 3 weeks, which showed a reduction in the size of the collection,

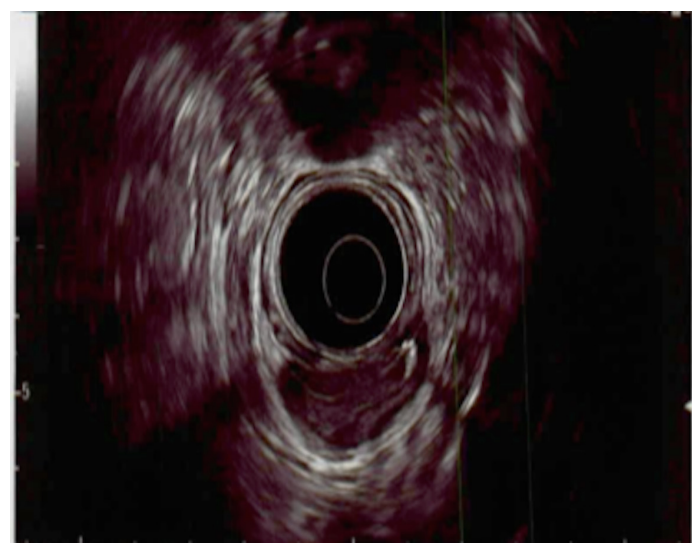

Figure 5 Oesophageal appearances at follow-up endoscopic ultrasound 4 months after admission - a hypoechoic region remains, but has reduced in size since initial endoscopic ultrasound .

with only a residual $3 \mathrm{~cm}$ distal oesophageal collection (figure 4). Likewise, repeat EUS showed that the size of the collection was significantly reduced (figure 5), which was felt to exclude a diagnosis of oesophageal wall tumour. The patient's symptoms resolved quickly and the patient remained well when he was reviewed at clinic 8 weeks after presentation.

\section{Learning points}

A dissecting oesophageal haematoma may present with dysphagia, chest pain and odynophagia. It can be precipitated by food bolus obstruction and may represent an intermediate stage between a Mallory-Weiss tear and Boerhaave's syndrome.

- A smooth submucosal lesion may be seen on endoscopy. Cross-sectional imaging in the form of CT or MRI are useful in characterising the nature of the lesion. We feel endoscopic ultrasound is the most useful investigation in the diagnosis of a submucosal haematoma.

- Management is typically conservative in nature with supportive care and monitoring for evidence of deterioration.

Contributors FM - responsible for writing article. JO - Responsible for editing article, oversaw writing of article. HK - supplied and interpreted CT images. SN supplied and interpreted EUS images.

Funding The authors have not declared a specific grant for this research from any funding agency in the public, commercial or not-for-profit sectors.

Competing interests None declared.

Patient consent for publication Obtained.

Provenance and peer review Not commissioned; externally peer reviewed.

\section{REFERENCES}

1 Cooray S, Dellaportas D, Caruana C, et al. Spontaneous intramural oesophageal haematoma in a patient with uncontrolled hypertension: An unusual chest pain aetiology. Case Rep Surg 2017;2017:1-4.

2 Herbetko J, Brunton FJ. Oesophageal haematoma: report of three cases. Clin Radiol 1988;39:462-3

3 Modi P, Edwards A, Fox B, et al. Dissecting intramural haematoma of the oesophagus. Eur J Cardiothorac Surg 2005;27:171-3. 
Copyright 2019 BMJ Publishing Group. All rights reserved. For permission to reuse any of this content visit https://www.bmj.com/company/products-services/rights-and-licensing/permissions/

BMJ Case Report Fellows may re-use this article for personal use and teaching without any further permission.

Become a Fellow of BMJ Case Reports today and you can:

- Submit as many cases as you like

- Enjoy fast sympathetic peer review and rapid publication of accepted articles

Access all the published articles

Re-use any of the published material for personal use and teaching without further permission

For information on Institutional Fellowships contact consortiasales@bmjgroup.com

Visit casereports.bmj.com for more articles like this and to become a Fellow 